\title{
Early Acceptance of Western Music in Indonesia and Japan Triyono Bramantyo*
}

Department of Music Education, Faculty of Performing Arts, Indonesia Institute of the Arts of Yogyakarta, Indonesia

*Corresponding author: Triyono Bramantyo, Department of Music Education, Faculty of Performing Arts, Indonesia Institute of the Arts of Yogyakarta, Indonesia, Tel: + 628999025757; E-mail: t_bramantyo@yahoo.com

Received date: September 3, 2018; Accepted date: September 18, 2018; Published date: September 25, 2018

Copyright: ( 2018 Bramantyo T. This is an open-access article distributed under the terms of the Creative Commons Attribution License, which permits unrestricted use, distribution, and reproduction in any medium, provided the original author and source are credited.

\begin{abstract}
Indonesia and Japan shared a rather similar historical background in their contact with Western music. Sixteenthcentury Indonesia and Japan, upon which these investigations would be based, marked the beginning of the early Western music acceptance, mainly through the Portuguese merchants and missionary activities in both countries.

It was especially the spice trade on the Straits of Mallaca that brought the Portuguese ships to land and noticed about what they called the 'spice island' (formerly Mollucas, now Maluku) of Indonesia in 1511. It was also in Mallaca that the Jesuits met the Japanese named Yajiro, who told about his country, became the first Japanese Christian and brought the Jesuits to Japan in 1549. Amongst so many kinds of the Christianity impacts, the introduction of Western music would become the main concerns in this paper. Sixteenth-century Gregorian songs can still be found in Maluku and Flores of Indonesia and in Kyûshû of Japan, even though, for the time being, its texts have become very corrupted.
\end{abstract}

Current musical life situation in Japan is said to be comparable with that of Western countries, as there are fine orchestras almost in every large city in Japan. In Indonesia, on the contrary, there is no single professional orchestra yet even in Jakarta today.

Keywords: Acceptance of western music; Current musical life; Indonesia; Japan

\section{Early Historical Background}

The arrival of the Portuguese merchants and missionaries in Indonesia and Japan in the sixteenth-century brought the introduction of Western culture in general, and Western music acceptance in particular. Portuguese impacts in both countries can be divided into four groups: i.e., religious, cultural, political and economic. In this paper, however, the author purposes only to mention the first two impacts, religious and cultural, in correlations with the first introduction of Western music in Indonesia and Japan, which can be said mainly through the missionary activity.

In addition with that, an account by Indonesian sociologist Ignas Kleden [1] tells that there are at least three necessary requirements of colonization to happen. First, the foreigners would not interest to occupy a country poor in natural resources. If there were no spices in the islands of Maluku; the Portuguese, the English, and the Dutch would not possibly to occupy the islands to do the monopoly in spice trade. Second, in order to mobilization, the colonizers would not interest to an island with a few inhabitants. Third, in order to win the political power the colonizers would search for an area where the system of administration that already existed [1]

Indonesia is geographically about six-time larger than Japan, has a population estimated at 266 million with more than 300 ethnic groups and local dialects of more than 700 languages being spoken despite the official language, the so-called Bahasa Indonesia. The diversity of Indonesia is a contrary to Japan where majority Japanese can be said to be a mono-race, speaks the Japanese language both as daily communication and as the official language. From cultural perspectives there are too many differences to be describe, despite that it would consume a lot of space here. Therefore, this paper would only focusing particularly on the early acceptance of Western music and current musical life in both countries.

Early Portuguese present in Indonesia can be described shortly as follows. When the Sultanate of Mallaca fell to the Portuguese power in 1511, Demak continued to expand independently and established commercial port and settlement at Bantam (now Banten) of western tip of Java. After Portuguese became so dominant in the Straits of Mallaca, the commercial activities in Indonesia through the Sunda straits were fully under controlled by Demak Kingdom from the port of Banten. The Sultanate of Pajajaran of west Java, which is close to Banten, permitted the Portuguese to erect its fortress at Banten in 1522, and thus the Portuguese gained their first settlement on Java. It was later on that from this settlement then that the so-called keroncong music of Tugu's genre was believed to has been derived.

Meanwhile, in Japan, the year of 1543 marked the arrival of the Portuguese castaways at Tanegashima off the shore of southern Kyushu. The lords of Kyushu saw a chance that by doing business with the Portuguese could benefit a source of wealth they needed in order to maintain their military strength. The story goes that when the Jesuit missionary, Francis Xavier, landed at Kagoshima in 1549, he was well received by the lord of Satsuma. So successful was the Jesuits worked in Kyushu that they were granted a monopoly of evangelization in Japan by Vatican. Since then on, the love of music of the Japanese people could not be disregarded. 


\section{Gregorian Chants in the 16th Century Ternate (Indonesia) and Funai (Japan)}

The writer convinced that it must not been written in Indonesian history yet that the Middle Age Western Gregorian Chants was not only had been introduced but even been sung by Indonesian Catholics in Eastern Indonesia more precisely in Ternate sometime as early as in 1536. Here is the narrative. Upon his own initiative, in 1536 Antonio Galvao, the Captain in the Ternate fortress, established a school for boys (Seminario) in which writing and reading Potuguese and singing the Cathecisms (Gregorian Chants) were introduced. It can be assumed that it was the first school of its kind in Southeast Asia, this, followed by the establisment of Hirado school in Japan in 1561 [2,3].

Franciscus Xaverius, the co-founder of Jesuit Society himself came to Ternate and here were some of his activities during his stayed there. In order to create a pleasant and effective way of conveying the Christian message, Xavier was so successful in combining the native love of music with the Catholic ritual. One of the accounts wrote by Andaya told us that "in the open square in Ternate and in the homes, the women and children at all times of the day sang the "Creed" (the Credo), "Our Father" (Pater noster), "Hail Mary" (Ave Maria), "the Confession" (Confiteor), and other prayers, the Commandments, and the Works of Mercy" [2]. Andaya cited Xavier who used to say proudly that "this program was so successful that in the fields and at sea the people sang these songs instead of their own secular songs" [2].

Accordingly, in the seminario of Ternate, the pupils had to take Latin as a compulsory subject despite another subjects such as logic, philosophy, theology, reading, writing composition, and Psalter. Moreover, the pupils had to assisted at the High Mass on Sundays and feast days where they sang Terce, Sext, Nones, and Vesper. Some of the Seminario of Ternate students (four Makasarese and six Malukans students) also be sent to the College of Goa and it was believed that they were the first Indonesian to be sent abroad as a group of foreign students, who formally had the first experience to study Western music, i.e., liturgical music, in a college which was centered for the Jesuits Mission in Asia [4]. According to Apel [5], the Gloria in Excelcis Deo was among the Christian hymns that were also sung in sixteenth-century Maluku.

Meanwhile about the history of Chatolicism in Japan with its impact of the introduction of Gregorian Chants in the country was told as followed. Before he came to Japan, Xavier had been told by a Portuguese captain about the Japanese fondness of music [6]. Thus when Xavier landed at an island called Tanegashima in 1549, he already had in his hands small catechisms translated into Japanese language with the help of Paul Yajiro.

The translation of cathecism was completed in 1553. According to Harich-Schneider [6], "Japanese musical terminology crept into this translation. The various parts of the Mass were term dan, like the dan in nô plays and kagura. There was 'Confisão-no-dan', Confiteor; 'Introito-no-dan', Introitus; 'Kirie-ireizon-no-dan', Kyrie eleison; 'Guroriya-no-dan', Gloria; and so forth" [6].

When we recalled the case of Ternate and Tidore of the Maluku mission work, we found the same phenomenon was also happened in Kyushu. The first school for boys was established in Bungo in 1561. The number of students in 1562 were 15 Japanese and Chinese boys. Reading, writing, Christian doctrine and music, especially singing, were taught [7]. By 1561 there have been five churches in Japan, those of Funai, Kyôto, Yamaguchi, Hakata and Hirado. In 1582, the Jesuit missionaries numbered 80 in 20 stations and several educational centers, with 200 churches and 150,000 converts" [8]. On his accounts, Takei described that "...on their way home from school, the children of Funai sang Miserere that even non-Christian adults could memorized the melody from listening it. In the school led by the missionary, the children were taught not only reading and writing Japanese, Portuguese, and Latin, but also singing the catechims and Gregorian chants." Furthermore, Takei told us that "the children have mastered to sing the 'Doctrines' both in Latin and Japanese language only in eight months since the school was opened" [9]. Pater noster, Ave Maria, Credo, and Salve Regina, were among the cathecims that the children sung every day at school. After the school time, the children stand in line before the cross, sung the Ave Cruz, and then returned home.

In addition of that, Ebisawa [7] convinced us about the prosperity and the successful of Western music cultivation in Japan when he said that the children not only learnt to sing but also learnt to play the instruments such as flute, shawm, and viola d'arco. On one occasion in autumn 1562, the children played the viola d'arco before the lord of Bungo, Ôtomo Sôrin. Father Luis de Almeida, as cited by Ebisawa [7], wrote that "these toddlers have shown sufficient ability even to perform before the pope in Rome" [7]. Not only the children could sing quite well, but also the adults now have already become good at singing in the polyphony. "During nocturnal services the women sat in the left transept of the church, the men in the right, and they sang alternately the antiphonies of the Epiphany, of the Glory of Paradise, of the Holiest Name, of the Cross, the Doctrine, of the Heathens' Blindness and the Deceitfulness of the Devil, all in their own language" [6].

\section{The Acceptance of Western Music and Its Implications}

First of all, the term 'acceptance' raised a number of questions as regards its meaning. "Do we really accept something, essentially and philosophically?"; in idea and practice, "why do we have to accept it, and what motivates us to accept it?", and, borrowing from Minagawa Tatsuo's [10] ideas "what significant bearing does it have on us (when we have accepted it) ?"; also, "what bearing should it ideally have on us?" [10]. Of course, there are many more similar inquiries. On the other hand, we also cannot circumvent questions that emerge from the term 'Western' such as; "what is 'Western' music anyway?", "does it fit our culture which is fundamentally oriental?", "have we agreed upon it by common consent, (to borrow Mantle Hood's terms) musically, culturally and socially?"[11].

All these questions require answers that we as Asians have not yet confirmed or, at least, which satisfy all of us. Minagawa Tatsuo [10] said that "Our forefathers of the Tempyô Era (period of cultural efflorescene in the eighth century following the assimilation of mainly Tang Chinese culture) and of the Tenshô Era (when Portuguese missionaries arrived) sacrificed not a little in their efforts to assimilate foreign culture and music. The problem they faced was precisely the problem we today must face and to which we must search for an answer. Japanese encountered with European music, then, could not be simply a matter of nostalgic retrospection, a mere review of a historical event of four centuries ago" [10].

Meanwhile on Indonesia side, Amir Pasaribu [12], an Indonesian composer and music critic, in 1955 wrote that "we do not refuse the idea of national music, but we also have to evaluate the subject proportionally"[12]. The idea of national music emerged especially on the surface of cultural polemics in the 1940s among Indonesian scholars who carried out a debate over East versus West as to what 
should be engaged as the sole national identity of a newly independent country.

Back in 1928, Indonesian youth leaders declared an oath of oneness, the so-called Sumpah Pemuda, which had proven amazingly successful in uniting the country as one nationality, one motherland, and one national language-Indonesian. Based upon this background, therefore, the foundation of the oneness in musical 'identity' or national music had to be sought. One idea suggested that Indonesian music should be represented by keroncong, while other ideas suggested that it must be gamelan. Neither the former nor the latter, however, could represent Indonesian identity, though.

Since the world has become globalized, the issue of Western or Eastern regarding the culture that must be adopted must have no longer relevant today. For instance, Pacific Music Festival held every summer in Sapporo, Japan, in which selected young musicians from worldwide would take to participate. Similarly, The Asean Youth Music Festival was also established for the purpose of forging global relationships among Southeast Asia nations. Therefore, music is no longer as issue of Western or Eastern, but belongs to human beings universally. These two international musical events have surely become a proven of our acceptance to the Western music.

Furthermore, music has been accepted widely as a universal language as Zuckerkandl [13] told when he said that as a universal language, Western music no longer belong to any nation. Everyone may participate in it, play it, learn about it, appreciate it and enjoy it. As a language it can say 'nothing', but again there is always 'something' in nothingness. Zuckerkandl confined that "if every thought is a thought about something, how is it possible to think nothing?"[13].

The people of Maluku in the sixteenth century had, to some degree, shown similarities with the people of Kyûshû in their acceptance of Western music. Like the people of Kyûshû, the Malukans were also fond of music as it told by Jaap Kunst [14].

One question emerges, however. Did the sixteenth century people of Kyûshû and eastern Indonesia had to accept European music along with Christianity unconditionally? The answer is yes. They were in a position of "unconditional surrender" [Hood. ibid. p.290], and thus they must had sacrificed a great deal in their effort to assimilate foreign music [10].

Similar implication had also happened for the Malukans where we found the lost of its cultural identity. Thus, the unspoiled remains of a cultural heritage could be seen only in some aspects of life [14]. The same phenomena can also be found in Nias of Sumatra where the impacts of the Rheinische Mission, even though was successful in converting almost the whole population of North and Central Nias, was such that "the culture of Nias was first systematically violated and destroyed in order to then sow the seeds of Christianity upon properly prepared soil" [14].

The term acceptance also brought some other implications of creativity to change or improving the musical elements they accepted. This implication brought us to a new genre that differs from its original. This genre called newly hybrid music with the characteristic of a mixture of foreign musical elements with the local taste. For instance of this kind is the keroncong music. Over all of the traces of the evidence of Western music acceptance in Indonesia, the so-called keroncong was the most popular form of popular music which history was completely separated from the religious element.
Judith Becker described keroncong as when she said that "keroncong is the generic term for popular, sentimental songs sung throughout Indonesia and generally believed to have been introduced by the Portuguese sometime around the sixteenth century. The European vocal phrases and the simple chordal accompaniment, usually played on a guitar, distinguished keroncong from indigenous forms of popular music" [15].

\section{Contemporary Discourse of Acceptance of Western Music}

The implication of this title perhaps, unintentionally, attracted our attention to the term acceptance and probably also the term Western, even though the latter might no longer be relevant to our so-called era of globalization. First the term 'acceptance' have raised a number of questions as regards with its meaning. Do we essentially accept something? Why do we have to accept it, and what motivates us to accept it? What significant bearing does it has on us (when we have accepted it). Finally, What bearing should it ideally have on us? [10].

In addition with that, we also cannot circumvent questions that emerge from the term 'Western' such as what is 'Western' music anyway? Does it fit our culture which is fundamentally oriental? Have we agreed upon it by common consent, musically, culturally and socially? [11].

All these questions required answers that should satisfy us all. An example answer from Minagawa Tatsuo [10] suggested that it was likely that the Japanese forefathers of the Tempyô Era (period of cultural boom in the eighth century following the assimilation of mainly Tang Chinese culture) and of the Tenshô Era (when Portuguese missionaries arrived) sacrificed not a little in their efforts to assimilate (read: accept) foreign culture and music. The problem they faced was precisely the problem we must have to face today and to which we must have to search for reliable answer. Japanese encountered with European music, therefore, could not be simply a matter of nostalgic retrospection, as well as a mere review of a historical event of four centuries ago" [10].

On the other hand, Amir Pasaribu, an Indonesian composer and music critic, in 1955 wrote that "we do not refuse the idea of national (read: Westernized) music, but we also have to evaluate the subject proportionally" [12]. The idea of national music emerged especially on the surface of cultural polemics in the 1940s among Indonesian scholars who carried out a debate over East versus West as to what should be engaged as the sole national identity of a newly independent country.

Based upon this background, the foundation of the oneness in musical 'identity' or national music had to be sought. One idea suggested that Indonesian music should be represented by keroncong, meanwhile another suggestion concluded that it should be gamelan. Neither the former nor the latter could represent Indonesian sole musical identity. Due to this fact, Amir Pasaribu said that "the problem of national music cannot be overcome by the hands of arts and cultural administrators". He went on to say that "the solution is lies inside music creation: ces't le tonqui fait la musique! Musical notes! And not by the somber words of musicians or culture scholars"[12].

Now after five centuries of Western music acceptance of Indonesia and Japan, have the discourse found its place in the development of music culture of both countries? Have the acceptance of Western music influenced the way of life of both people of the two countries? 
Page 4 of 5

Certainly Indonesian people have no objections in accepting Western music since its introduction of Western Gregorian Chants in the early sixteenth century. There are some of the old European songs have found in Flores, and the present of popular keroncong was the evidence for the early acceptance of Western music by Indonesian as well. Moreover, the Sultanate Palace of Yogyakarta, under Sultan Hamengku Buwono VI (r.1855-1877), had managed a courtly symphonic orchestra and built a chapel inside the palace as well as a concert hall outside, and even had opened a settlement for court musicians in an area still known today as the kampung Musikanan (the musicians' settlement).

Thus, in Indonesia's case, the early accepting of Western music in Indonesia was the product of not only Christian activity, but also Islamic. Judith Becker, in her "Traditional Music in Modern Java" noted that a "visitor" went to the palace of Yogyakarta and Surakarta. Becker also noted that the early nineteenth century was marked a period when things European were fashionable in Indonesia. "There was ample opportunity for the members of the court, including musicians, to become familiar with European modes of thought, European biases about music, and European musical notation systems" [16].

Some decades earlier following the Meiji Restoration in 1868, Japan was began reopening the country and a period of things European, contrasted with a two hundred year era of seclusion. In contrast with that of Indonesia, Japan was indeed more progressive in its acceptance of Western music. The Ministry of Culture and Education sent music educators to the United States and conversely invited American music educators to work in Japan. Izawa Shûji (1851-1917), a Japanese music educator, and his counterpart, an American music educator, Luther Whiting Mason (1828-1897), played a significant role in the first decades of the foundation of Western music in early nineteenth century Japan. One of its success was the establishment of the most prestigious university of arts in Japan, the so-called Tôkyô University of Arts, firstly founded as Tôkyô School of Music and Gagaku on October 5, 1887, shortly after the previous Ongaku Torishirabe Kakari (Committee for Music Research) was closed [17].

The periods following the Meiji Restoration saw Japan emerge as a developed country, ranking as Asia's most prosperous country. Musical life prospered with the foundation of one prefectural or city symphony orchestra after another. The same happened with the establishment of well-equipped prefectural or public concert halls number more than two hundred. In the field of education, music became a compulsory subject in primary and secondary schools. Children learned the piano or other instruments from an early age.

Almost every school has maintained groups of choirs, recorder ensembles, brass bands, etc. Systematic tuition from senior students to juniors has proved to be the most successful method applied in schools and universities. But there is a lot more to be added here. Children who wish to become musicians must have very heavy schedules in order to attend special music high schools which now number about sixty, followed by some 120 music faculties and departments in universities and short-course colleges [18].

Japan has also produced world-class composers, conductors, and music players, who work either in Japan or in foreign countries. In order to enhance the dynamism of its musical life, Japan has also invited world-class foreign composers, conductors, and music players to give concerts, tutorials, master classes, and music workshops in Japan. There is actually a lot more that can be added here, but I should quit it before my jealousy grows deeper.
What can be summarized about musical life in Indonesia and Japan after they committed themselves to accept Western music? Both countries have shared the same thoughts from the very beginning. This is summarized by Amir Pasaribu of Indonesia when he says: "Why should we object to accepting Western music, and why bother with the idea of national music?" [12].

Similarly, Izawa Shûji of Japan pointed more specifically that, "The aim of establishing music as a compulsory subject is to produce a new national music by synthesizing Japanese and Western music" [18]. However this is a long process and perhaps we have to wait a while before another Takemitsu is born and again perhaps even longer before an Indonesian composer of similar stature to emerge. It indeed sounds like utopia, but, being an optimist, I would rather say there are always possibilities waiting before us someday in the future.

\section{Conclusion}

Finally, a reflection, rather than a conclusion, can be described as follows. First, Japan has become Asia's Vienna. Secondly, Japan has produced major music players in the most of well-known orchestras of the world. Thirdly, there are qualified music conservatories, great orchestras, fine concert halls as well as huge number of fine musicians that make the life of music in Japan is the best in Asia.

Meanwhile, in Indonesia, the situation is on the contrary. The development of Western music is not that fruitful unless only in the life of popular music industry. School music education from high school level to the first degree level is not well-equipped and thus its products are not the level of good musicians capable of playing in the world orchestras. Its need more serious attention from the government in order to improve the music education and musical life in Indonesia as a consequence of our acceptance of Western music. We need to learn from Japan if we want to gain a level of prosperous from music like the Japanese does.

\section{References}

1. Kleden I (2018) Sejarah Kolonial dan Kita" (The History of Colonization and Us) in Daily Kompas.

2. Andaya LY (1993) The World of Maluku: Eastern Indonesia in the Early Period. Honolulu: University of Hawaii Press.

3. Pinto da FA (1971) Influenza Portuguesa na Indonésia. Lisboa: Centro de Estudos Historicos Ultramarinos.s

4. Schurhammer SJG (1980) Francis Xavier: his life and times, Vol. III, Indonesia and (India); 1545-1549, Joseph M. Coestelloe (tr.) Rome: The Jesuit Historical Institute.

5. Apel W (1958) Gregorian Chant. Bloomington, IN: Indiana University Press.

6. Harich-Schneider E (1973) A History of Japanese Music. Oxford University Press, London.

7. Ebisawa A (1983) Yogaku Denraishi: Kirishitan Jidai kara Bakumatsu made ('Introduction of the Western Music: from Christian Period until Bakumatsu'). Tokyo: Nihon Kirisuto Syuppan Kyoku.

8. Anesaki M (1963) History of Japanese Religion: With Special Reference to the Social and Moral Life of the Nation. Tokyo: Charles E. Tuttle Company Press.

9. Takei S (1995) Nanban Ongaku; Zabivier ga Tsutaeta Inori no Uta, sono Hikari to Kage ('Southern-Barbarian Music: the Light and Shadow of the Prayers' Songs Brought by Xavier'). Tokyo: Ongaku no Tomosha.

10. Minagawa T (1976) Yôgaku Koto Hajime ('The Beginnings of Western Music'), a program's note, English translation by Taneda Terutoyo and Shizuyo Becker, in Toshiba-EMI Limited, TW-8002-3, Tokyo. 
Citation: Bramantyo T (2018) Early Acceptance of Western Music in Indonesia and Japan. Arts Social Sci J 9: 408. doi: $10.4172 / 2151-6200.1000408$

Page 5 of 5

11. Hood M, Brook BS, Downes EOD (1972) The Consensus Makers of Asian Music. In: Perspectives in Musicology (1stedn), New York, NY: W.W. Norton \& Company Inc.

12. Pasaribu A (1955) Music and Its Circumstances. Djakarta: College Library, Ministry of Education and Culture.

13. Zuckerkandl V (1973) Man the Musician, Sound and Symbol, Volume Two. Pronceton, NJ: Princeton University Press.

14. Kunst J (1994) Ancient Western Songs from Eastern Countries", in Indonesian Music and Dance; Traditional Music and Its Interaction with the West, a compilation of articles (1934-1952) originally published in Dutch, English translation by Sandra Reinjhart, with biographical essays by Ernst Heins, Elisabeth den Otter, and Felix van Lamsweerde. Amsterdam: Royal Tropical Institute, pp: 155-172.

15. Becker J (1975) Kroncong, Indonesian Popular Music. Journal of the Society for Asian Music, Vol. VII-I. Southeast Asia Issue, pp: 14-19.

16. Becker J (1980) 'From Oral to Written Tradition in Javanese Music', in Traditional Music in Modern Java: Gamelan in a Changing Society, Honolulu, HI: The University of Hawaii Press, pp: 11-25.

17. Hamano M and Hattori K (1976) Ongaku Kyôiku Seiritsu no Kiseki ('The Locus of the Formation of Music Education'), Tokyo: Ongaku no Tomosha.

18. Oku S (1975) Music Education in Japan, Nara: Kansai Insatsu Ltd. 